\title{
The Impact of Teaching Methods and Materials on the Teaching of Citizenship Education in Cameroon: A Study of Case Schools in Buea Municipality
}

\author{
Fedelis Lekeaka Alemnge, Betrine Anyere Andongaba \\ Department of Curriculum Studies and Teaching, Faculty of Education, University of Buea, Buea, Cameroon \\ Email: alemnge.fidelis@ubuea.cm, anyereandongaba2000@gmail.com
}

How to cite this paper: Alemnge, F.L. and Andongaba, B.A. (2021) The Impact of Teaching Methods and Materials on the Teaching of Citizenship Education in Cameroon: A Study of Case Schools in Buea Municipality. Open Access Library Journal, 8: e6993.

https://doi.org/10.4236/oalib.1106993

Received: November 14, 2020

Accepted: March 28, 2021

Published: March 31, 2021

Copyright $\odot 2021$ by author(s) and Open Access Library Inc.

This work is licensed under the Creative Commons Attribution International License (CC BY 4.0).

http://creativecommons.org/licenses/by/4.0/

(c) (i) Open Access

\begin{abstract}
The purpose of this study was to investigate the impact of methods and materials on the teaching of Citizenship Education in Secondary Schools in the Buea Municipality. Two research questions were formulated to guide the study: To find out how teaching methods influence the teaching of citizenship, and how the use of instructional materials influence the teaching of citizenship in secondary schools in Buea Municipality. The study adopted a qualitative approach, using the multiple case study design to carry out the investigation with the help of an interview and an observation schedule. It involved 6 citizenship education teachers from 3 sampled case schools; Summerset Bilingual High School Molyko, Government Bilingual Grammar School Molyko, and Baptist high school Great Soppo. The purposive sampling procedure was used to select the participating schools and teachers of the study. Two teachers were interviewed, and one teacher observed in each school, to find out whether the methods and materials used were in line with those proposed by the syllabuses. The data from interview and observation were transcribed and coded thematically. The findings showed that citizenship education teachers use mostly teacher-centered methods in teaching, in contradiction to the learner-centered methods prescribed in the syllabus. Teachers do not have the subject syllabuses and so rely on textbooks for their teaching of the subject.
\end{abstract}

\section{Subject Areas}

Education

\section{Keywords}

Teaching Methods, Teaching Materials, Influence, Citizenship Education, 
Secondary Schools, Syllabus

\section{Introduction}

\subsection{Background}

Interest in citizenship education has escalated worldwide in recent years. This dimension of education has been viewed by some as an opportunity to begin preparing young people for their understanding of, and involvement in, the civic life of their community(ies), from the local to the global spheres. For others, it has been viewed as a way of responding to a range of existing social concerns including: a lack of civic literacy among youth; an increasing democratic deficit; racism and cultural conflict, and low levels of participation in both elections and in civil society organisations among the youth. Whatever the reason, there has been a proliferation of research studies, formal discussions, and curriculum initiatives throughout the world, as teachers, policy makers, and researchers attempt to understand and assess the complex processes by which teachers teach citizenship education in schools (Crick, 2000) [1]. What teachers know and do is one of the most important influences on what students learn (Darling-Hammond, 1998) [2]. If teachers are trained, have knowledge in using the different teaching methods and materials, and assess students in the classroom, the students will learn well, and the goals and objectives of citizenship education would be achieved. But, if the teachers do not possess adequate pedagogic knowledge in teaching the subject, the attainment of objectives will be farfetched, and this would have a negative influence on the learners' behaviour, thereby producing youth who would be a nuisance in the society and the world at large.

Citizenship education was first taught as civic education in Cameroon schools from June 1959 under the supervision of the Secretary of State for Mass Education and Information for Youth and Sports. From September 2011, it was moved to the Ministry of Youth Affairs and Civic Education (Atabong, 2013) [3].

The evolution of the subject has been an issue of national concern. Besides, the status of citizenship education in Cameroon has been regarded to be very important as seen in the constitutional evolution that the country has witnessed from the 1960 through the 1961, 1972, 1985 and 1996 constitutions. As part of its implementation, Ministerial Order No 30/05/MINESEC/IGE/IGP/SH of $12^{\text {th }}$ April 2005, established the "Citizenship Education Syllabuses" in general and Technical Secondary School in particular, with the following important policy objectives:

1) At the level of the individual, the school was to guarantee the physical, intellectual, artistic, civic and moral education, as well as contribute to the full blossoming of the child's personality.

2) At the community level, the school should ensure the training of citizens respectful of community property, knowledgeable, and rooted in their culture, 
and open to the world.

3) From the moral dimension, the schools ought to promote a three-dimensional code of ethics, namely: personal, family and interpersonal ethics.

4) From the political and civic points of view, the school should be able to initiate the child to democratic principles and practices, respect for one another, tolerance, peace, justice, dialogue, solidarity, and cooperation. It should inculcate to learners the sense of dignity and honour, love for job well done, respect for the general interest, and acceptance of differences. It should train citizens to become highly involved in civic duties, love for fatherland, national unity, and promotion of official bilingualism as well as sub-regional integration.

5) In the economic domain, the school should ensure that the end product of the educational system be economically productive, enterprising and endowed with initiatives like to make him creative, self-employed and capable of adapting to the evolution of science and technology at all time (pp. 3-4).

\subsection{Statement of the Problem}

Pedagogy is a central element in any teaching and learning process. Consequently, curriculum experts are ceaselessly exploring ways of designing learning programmes that maximise learning. The needs of Twenty First Century education as expressed in international educational forums and crystalized in the Sustainable Development Goals (goal 4) requires that education provide learners not only knowledge, but also competences and suitable attitudes to serve both the national and the global community. In this light, and in her quest to transform its economy and become an emergent nation by 2035, Cameroon has undertaken reforms in the area of education leading to a revision of all its programmes from basic to tertiary education. In her search for an appropriate pedagogy, Cameroon has adopted a learner-centred pedagogy buttressed by the approach to develop knowledge and know-how in the learners through assisting these learners develop certain defined core skills and transversal competences.

In this connection, it is necessary to determine whether teachers have made the required shift in their pedagogic practices to ensure both the successful implementation of the revised citizenship syllabus and ensure the required transformation is taking place in the learners.

\subsection{Research Questions}

1) To what extent does the use of instructional materials influence the teaching of citizenship education in schools?

2) To what extent does the use of teaching methods influence the teaching of citizenship education in schools?

\section{Literature Review}

\subsection{Teaching Materials}

Karla, (2007) [4] considers teaching materials as partial construction of knowl- 
edge. He adds that these materials are described as artefacts that in some cases, by using different forms of symbolic representation, and in other cases as direct references of objects incorporated into teaching strategies, help to reconstruct knowledge through the creation of partial meanings of the curricular concepts. The manner in which these materials are used in schools, or specifically, in classrooms may enhance the student's understanding, interpretation and application of the knowledge gained. When appropriately used, teaching materials portray and develop specific perceptions. They also elicit and shape concepts in teachers and students' minds, and develop critical thinking alongside building learners' motivation to learn and discover more. Johnson (1998) [5] added that instructional materials are the collection and selection of resources, which are applied and integrated into a systematic process of teaching and learning to make learning effective. Instructional materials can be physical or concrete objects, locally made or imported. They can also be objects or devices, visual, audio or audio-visual, which enhance or facilitate effective teaching and learning, (Ogbondah 2007) [6].

For quality instruction to be achieved, Ogbondah (2007) [6], opined that the teacher's level of resourcefulness and creativity in the identification and use of instructional materials is very important. Tambo, (2003) [7] just like Ogbondah, identifies educational media as the various teaching materials and devices that are capable of teaching on their own, or assisting a life teacher to facilitate teaching. He classified teaching materials into basic and advanced educational media, and posited that basic educational media adequately apply to the Cameroon educational context where visual display devices, graphic materials, print materials, models and real things are found. Advanced educational media on the other hand are those instructional materials which are relatively complicated to be used, and where infrastructure to support their use in Cameroonian classrooms are yet to be fully developed, for instance electronic media, television, computers, and web-based resources.

Flaming and Mills (2011) [8] explained that instructional materials are in various classes, such as audio or aural, visual or audio-visual. Thus, audio instructional materials refer to those devices that make use of the sense of hearing only, like the radio, audio tape recording, and television. Visual instructional materials on the other hand, are those devices that appeal to the sense of sight only, such as the chalkboard, chart, slide, and filmstrip. An audio-visual instructional material, however, is a combination of devices which appeal to the sense of both hearing and seeing, such as television, motion picture, and the computer. Among the instructional materials the classroom teacher uses, the visuals out-number the combination of the audio and audio-visuals. This largely addresses the needs of all learners in the classroom, be it visual, auditory and/or kinaesthetic. This is corroborated by Russel (2006) [9], who agreed that this category of instructional materials is used in most learning environment since it doesn't require too much expertise to manipulate such materials. 
The second category is made up of the print and non-print materials. The former includes materials such as; books, journals, maps, graphs, while the latter, television, specimen, and chalkboard. This category of instructional materials is highly used since its application can be done in all learning environments.

The third category is made up of hardware and software materials. The hardware materials include; chalkboard, television, radio, and software include maps, graphs, posters and cassettes. However, before any of these materials is selected and used, it is suggested that they satisfy certain conditions. These include; the relevance of the materials to facilitate teaching and learning; the material must be clear, precise and portable; the teacher must take into consideration the learners' characteristics; the age of the learners must be taken into consideration; the materials must be reliable; and they should be made visible to all learners.

Jesús (2002) [10] argued that citizenship education instructors like those of other subject face difficulties with the utilization of instructional materials, and that this results from insufficient knowledge about the availability of these materials, difficulty in selecting and using them appropriately, financial difficulties of teachers and institutions, and non-availability of electrical power supply among others. He further explains that teachers also face a lot of challenges in selecting textbooks that will provide the relevant content in teaching the subject because citizenship education is a broad field where topics and lessons cut across disciplines. This poses a lot of problems for teachers to extract materials from areas out of their subject disciplines. Besides, since the subject is new as compared to the other social science subjects such as history and geography, the textbooks to meet the Cameroon realities of the subject may not yet be sufficiently available.

\subsection{Teaching Methods}

According to Loyens et al. (2005) [11], teaching methods used by the teacher in the teaching and learning process will depend on the characteristics of the learners (age, backgrounds), the type of lesson and the educational objectives of the school. Bame (2004) [12], classifies teaching methods such as lecture, illustration and demonstration under teacher-centred methods, and discussion, group work, and assignments under learner-centred methods. Bame added that in the teacher-centred approach to teaching, teachers are the main authority figures in this model. Students are viewed as "empty vessels" whose primary role is to passively receive information with an end goal of testing, and assessment. It is the primary role of teachers to pass knowledge and information onto their students. In this model, teaching and assessment are viewed as two separate entities. In the student-centred approach to learning, while teachers are the authority figure in this model, teachers and students play an equal and active role in the learning process. The teacher's primary role is to coach and facilitate students learning and overall comprehension of material. Student learning is measured through both formal and informal forms of assessment, including group projects, student portfolios and class participation. Teaching and assessment are connected or in- 
corporated; students' learning is continuously measured during teacher instruction. Dean (1982) [13] advocated that the teaching learning process is only balanced when the two features of teacher-centred and learner-centred methods of teaching are used together in the teaching and learning process, because the method that the teacher uses will depend on the situation that he/she experiences in the classroom with the learners. Bame (2004) [12], further proposes that the selection of teaching methods should respect certain principles. It should be in accord with principles of learning, be appropriate to the objectives and desired behavioural changes, be in accord with the teacher's ability to use it effectively and creatively, take into consideration the capacity of the learners, and must be closely related with the subject matter to be taught. Also, it should be very flexible such that the teacher can easily change it in the teaching and learning process. In this light, Keller (2005) [14] advises that when selecting instructional delivery methods, initial consideration must be given to learned capabilities and the type of performance expected of learners as a result of instruction so as to avoid critical errors in the selection process.

\subsection{Lesson Preparation and Delivery}

Constantino (1994) [15], advocated that a yearly lesson plan or overall yearly plan provides an overview of the course in curriculum. It indicates the units to be taught and the time devoted. Yearly plans are usually submitted to the Dean of Academics, who is usually an assistant or Vice Principal, either directly by the teacher or through Department Heads at the end of first week of instruction of the respective academic year.

Yearly lesson plans contain the units to be taught along with the subtopics, and serve as a guideline when preparing the weekly lesson plans that consist of the daily lesson plans. Yearly lesson plans also include major curricular and extracurricular activities to be performed, without going into their details, especially if they are to be performed when transiting from one unit to another.

A daily lesson plan is a written account of what a teacher would like to have happen during a certain lesson or class period. It should contain the concept or objective, the time block, the procedure, the instructional materials needed, and the assessment methods. Daily lesson plans are submitted to Vice Principals or to the Department Heads at the end of each week for the following week. The first year teacher must realize that as a general rule, it will be necessary to plan in considerable more detail than the teacher with more experience and training (Cicek, 2013) [16].

Before writing-up a lesson plan, the teacher should first be aware of the learning styles of the students, reading levels/skills of students, and inventory access to technology. The question to ask when preparing lesson plans is what students are going to learn, achieve, and accomplish tomorrow, and not what the teacher is going to cover tomorrow because the role of the teacher is not to cover; it is to uncover! Learning has nothing to do with what the teacher covers. Learning has 
to do with what the student accomplishes.

Based on the answers to these questions, the teacher should prepare the lesson plan, establishing a variety of instructional strategies and focusing on academic expectations and core content to connect writing to what is being taught. More specifically, a lesson plan should address the following, according to Richards (1998, p. 103) [17]:

1) Concept or objectives to be taught, which tells the student what they will learn.

2) Time blocks, e.g., approximate time expected to be devoted to the lecture.

3) Procedures to be used for instructional design.

4) Materials needed both for the student and the teacher.

5) Independent practices or student time on task.

6) Evaluation, applications, and student understanding, e.g. main questions to be asked by the teacher to check student understanding.

\subsection{Theoretical Review}

Bloom's (1968) [18] Mastery Learning Model is based on the argument that every individual can learn and achieve the stated goals and objectives of the lesson. But the duration needed for such mastery differs from one learner to the other, because in every learning environment, each learner takes a different pace to understand concepts. Bloom further explained that some students do well, some averagely, others below average, and others poor if instruction does not take place. But this should not be so if instruction takes place because teachers should be able to use the different teaching methods, materials and assessment techniques to ensure that all the learners move at the same pace for the goals and objectives of the lesson to be achieved.

Instructors should be able to foster learning by scaffolding (supporting) learners at points where their natural aptitude might limit learning. However, Bloom argued that, $90 \%$ of students can master what they are being taught and that the responsibility of the teacher is to find the means which will enable learners master the subject matter by knowing their individual differences and learning abilities. He discussed features or elements of quality instruction that can promote mastery among most learners. They are; cues, participation, reinforcement, and feedback/correctives. Cues are communications to the learner as to the requirements of the learning task, and how to go about meeting these requirements. Participation involves covert or overt active practice with the learning task. Bloom suggested that reinforcement, whether positive or negative, should be given to learners by teachers, peers, or other adults to indicate approval of positive learning performance, and disapproval of poor performance. Feedback and corrective procedures follow participation or interaction by the learner. They may include alternative cues or additional time for practice. Bloom believes that mastery learning involves certain processes such as teach, assess, re-teach, and re-assess. If this process is followed by teachers, students would 
understand the concepts taught. Their individual problems that inhibit learning would be identified, and solutions provided to ameliorate the situation.

Keller's (1987) [19] Active Participation, Relevance, Confidence, and Satisfaction (ARCS) model of motivation is based on the fact that there are four key elements in instruction that encourage and sustain students' motivation. The role of the teacher is to identify and use them appropriately to stimulate learners to acquire knowledge.

Active participation means that teachers should give all learners equal opportunity to take part in the teaching and learning process. Teachers must stimulate learners' curiosity by posing challenging questions or problems to be solved. Methods for grabbing the learners' attention include the use of strategies such as games, role play or other hands-on methods to get learners involved with the material or subject matter. Keller explained that to better reinforce materials and account for individual differences in learning styles, teachers should use varieties of methods in presenting materials (e.g. use of videos, short lectures, and mini discussion groups). Therefore, heterogeneous groups should be constituted in class to attain this condition.

The students should find the lesson or topic very relevant. This would boost their learning abilities. The program design should match with the need of the learners. The objectives of the lesson should be communicated to them before its presentation so that they would be motivated to learn. Keller described six major strategies to be used by teachers to make the lesson relevant to learners. They are; Experience (tell the learners how the new learning will use their existing skills), Present Worth (tell the learners the relevance of the subject matter), Future Usefulness (tell the learners the future use of the knowledge acquired), Needs Matching (teachers should take advantage of the dynamics of achievement, risk taking, power, and affiliation), Modelling ("be what you want them to do!"). Other strategies include guest speakers, videos, and having the learners who finish their work first to serve as tutors), and Choice (allowing the learners to use different methods to pursue their work, or allowing them to choose how to organize it).

Confidence can be gained through the support learners get from teachers. Teachers should ask prompting questions to enable the learners think out of the box. Also, the questions posed by teachers should take into consideration student's ability. Teachers should present the subject matter chronologically (i.e. from simple to complex, near to far, and known to unknown). This will enable learners get the prerequisite knowledge that will help them tackle complex issues in the course of the program. Learners should feel some degree of control over their learning and assessment; they should believe that their success is a direct result of the amount of effort they have put forth.

For a student to be motivated, he/she should be satisfied. Learners are satisfied when they realise that they have learned something. They develop confidence in themselves when they feel that they have studied something. This is one of the 
major factors that motivate learners intrinsically to put in more efforts in acquiring knowledge. Teachers should make the learners feel as though the skill were useful or beneficial by providing opportunities to use newly acquired knowledge in a real setting.

\section{Methodology}

Case study is "an ideal design for understanding and interpreting observations of educational phenomena" (Merriam, 1988, p. 2) [20]. An exploratory case study is appropriate to study areas in education "where little research has been conducted" (Merriam, 1988, p. 38) [20]. The design is a multiple-case study involving three secondary schools in the Buea Municipality. A multiple case study is a careful examination of similar cases to get in-depth result concerning a particular problem by triangulating data and reporting (Stake, 2006, p. 82) [21].

The population consisted of 36 ( 15 Government, 11 denominational, and 10 private) secondary schools in the Buea Subdivision. The purposive sampling technique was used to select 3 case schools representing each school type in the general population. Therefore, Baptist High School (BHS) Soppo, Bilingual Grammar School (BGS) Molyko, and Summerset Comprehensive College (SUBICOL) Buea constituted the sampled schools for the study. Bilingual Grammar School Molyko-Buea was created in 1963 by a presidential decree, and the school became operational in Man O War Bay, in Victoria (Limbe) in 1964. Some years after, the school was transferred to its present site at Molyko-Buea. It has a student population of 3465 students and 250 teachers. The school runs concurrently on the same campus an Anglophone stream, and a Francophone stream, from form 1 to 7 . Summerset Bilingual College is a lay private institution found in Molyko, Buea in 2000. It has a student population of 1000 and 80 teachers. Baptist High School was created in 1976. It has a student population of 600 , and 40 teachers. Citizenship education has been offered in these schools since they opened their doors to the public. The teachers sampled have been teaching the subject for over 7 years, and therefore, provided pertinent information required for the study.

Data were collected through the use of an interview schedule, and an observation schedule. Interviews conducted with the teachers, using the interview schedule, which consisted, 5 sections with each addressing one of the research questions of the study. Section A had four questions, section B 6, and sections C and $\mathrm{E} 3$ questions each. The interviews were conducted in the staffroom of each school on an agreed date, and each lasted 30 minutes. The interviews were tape recorded and later transcribed for analysis. Each participant was interviewed twice, and three observations carried out in his/her class within the month. All the teachers who participated in the study had a workload of 16 periods a week.

An observation schedule was used to observe classroom teaching and learning in order to obtain firsthand information on how citizenship education teachers make use of the teaching methods, instructional materials, and assessment 
methods in the presentation of the lesson to the learners, and also to determine whether these activities are in line with those prescribed by the syllabus. Three teachers, one from each sampled school, were observed three times, during a period of one month.

\section{Findings}

\subsection{Findings about Teaching Materials}

The researcher interviewed the participants to find out the types of materials they make use of in the teaching of citizenship education, and also to check whether they were in line with those prescribed by the syllabus. After the interview, the researcher took time to observe the teachers teach so as to find out whether the materials selected were appropriate for the lesson, whether they take into consideration learners' characteristics and whether they enhance learners' acquisition of knowledge. In addition, the teacher's mastery in the use of the materials was checked. The major themes that emerged were; the syllabus, schemes of work, textbooks, charts, and computers.

The respondents were asked if they possess a copy of the syllabuses that prescribe the materials, methods, and assessment strategies for the teaching of citizenship education, and how often they make use of them, and their relevance in the teaching of citizenship education. The interview data showed that 3 of the respondents depend on their personal schemes of work, and have never seen or used the new subject syllabus; that 1 of them relies on the copy of the new syllabus found in the school library, and only uses it when it's available, while the other has a personal copy of the new subject syllabus, and uses it regularly in teaching as contained in the following excerpts.

Respondent D:

No I don't have a copy of the syllabus. This is because it is very hard to find one so I don't make use of it. I depend on my scheme of work where the topics and lessons are found. I don't have any problem with it because I think it has no major difference with the syllabus. More still, I have been using my scheme for more than a year now, and it has not posed any threat as far as my teaching is concerned.

Respondent E:

No I don't have a copy of the syllabus. I use my scheme of work instead and am very comfortable with it because it supports my teaching. I have been hearing about the new syllabus for the teaching of citizenship education, but I have never set eyes on one. Even in the school library where some of these documents are found, I have never seen the one for citizenship education.

Respondent A:

I don't have a copy of the syllabus. More to that, I have not seen or used one 
in the last 2 years. I use my textbook which has all the topics and lessons needed to teach the learners.

Respondent B:

I don't have a copy of the syllabus but I make use of the one found in the school library whenever I want to go to class. It is a very important pedagogic document to me because it really helps me to familiarise myself with the different subject matters, teaching methods, materials and assessment techniques required to present the different lessons to the learners.

Respondent F:

Yes, I do have my syllabus for citizenship education. It is my working document always in my bag. I cannot go to the classroom without glancing through it. In fact, I make use of it on regular basis. It is very important for the teaching of citizenship education. My regular use has made me to become a better citizenship education teacher.

The researcher interviewed the teachers to find out whether instructional materials are relevant in the teaching of citizenship, and also to know the type of materials which they use in teaching. All the respondents agreed that instructional materials are very important in the teaching of citizenship education, but that most of them rely on using textbooks and charts in teaching because of lack of the needed teaching materials in school, lack of assistance from the school, and the high cost of affording them as well as in taking students out on excursion. Only a single respondent agreed that he has been making use of computers.

Respondent D:

Instructional materials are very important in the teaching of citizenship education. I make use of charts and textbooks, and do not use others because of cost. Besides, computers, resource persons and transporting the learners to educational sites, such as museums and monuments, are very expensive to sponsor. The Department is not ready to finance such projects, so I only rely on my textbooks and sometimes charts.

Respondent C:

Teaching materials are indispensable in the teaching of citizenship education because they help the learners to better understand concepts. I use textbooks and sometimes charts because the other materials proposed by the syllabus are costly. Besides, taking learners to monuments and also inviting a resource person is very expensive. The school is not doing anything to encourage the availability and use of the materials suggested by the syllabuses.

Respondent $\mathrm{F}$ added:

Instructional materials are very important in the teaching of citizenship 
education because they enable students to view concepts in a real life situation. I make use of textbooks, charts and sometimes computers. I don't make use of the other materials proposed by the syllabus because of the cost. There are no funds allocated for excursions, invitation of a resource person etc., so I tend to use my textbooks, charts and sometimes my private computer of which the school environment does not even support its usage.

All the respondents contributed in proposing that the government should not only propose materials to be used in the teaching of citizenship but should also ensure the availability of the materials in schools through the creation and maintenance of a resource centre, and that the school administration should ensure that the learning environments facilitate the use of these materials. All their comments were summarized in these words:

A resource center should be made available in schools and finances should be put in place to ensure that resource persons are invited at any time, and also to make it easier for the transportation of the learners from one monuments, and museums to another. Also, the power system of the school should be arranged such that it would facilitate the use of modern materials like computers. If all these proposals are taken into consideration, then I think the teaching of citizenship education would not be an issue, and the goals and objectives would be achieved.

From the data collected from classroom observation, what respondent " $D$ " said during the interview was in line with his classroom practice. He came to class only with a textbook and a notebook. The students were very passive because he only concentrated on pouring notes on them. If he had made use of a resource person like the Governor, D.O, Mayor, or Chief, it would have been better because the learners would have seen the practical aspect of the lesson, since it centered on the functions of administrators in a region. So, the choice of instructional materials was not appropriate for the lesson because it did not promote the acquisition of knowledge.

It was also observed that respondent " $\mathrm{C}$ " does not even make use of charts as he said during the interview. A very practical lesson, which was based on the "Description of National Symbols", requires the use of charts where symbols such as the seal, the flag, etc. were to be drawn, or the use of computers where these symbols were to be displayed, was neglected. An audio of the national anthem was not even made use of. He used the pure lecture method by putting himself at the center of the teaching and learning process, and then reading out the notes for learners to copy. This made the learners to be very passive. The Discussion Method and the use of a chart andlor computer would have made the class more interesting.

Findings gathered from the use of instructional materials in the teaching of citizenship education reveal that most teachers do not have the syllabus which is a very important document vital in the teaching of citizenship education. The 
findings also reveal that most teachers depend on textbooks in teaching the subject, and this discourages learners from acquiring the necessary competencies needed to live in society. Equally, monuments, computers, resource persons, museums, etc., which are modern instructional materials proposed by the syllabus, are not made use of by the teachers due to their unavailability, and lack of finance to sponsor the movement of teachers and learners from one learning environment to another, and the invitation of resource persons.

\subsection{Findings about Teaching Methods}

Participants were interviewed to find out the type of teaching methods they make use of in the teaching of citizenship education, and the extent to which it promotes learners' acquisition of knowledge. After the interview, the researcher observed that some of them teach to find out whether the methods selected were in line with the ones proposed by the syllabus, and whether it was also appropriate for the lesson. The themes generated here are Lecture Demonstration, Illustration, and Discussion.

All the respondents affirmed that they make use of the lecture demonstration method in the teaching of citizenship education and that it highly promotes learners' acquisition of knowledge as expressed in the following quotations.

Respondent D:

I always make use of the lecture demonstration method to teach citizenship education. For me, lecture addresses all the issues learners bring into the learning environment. My choice of the lecture demonstration method is because I use textbook in the teaching of citizenship education. So, this method facilitates the use of this material. Also, lecture demonstration makes learners to feel the presence of the teacher, and also encourages them to participate in the lesson.

Respondent E:

I use lecture demonstration in the presentation of lesson to the learners. This is because I think the lecture method makes the learners to listen and also contribute to the implementation process because it creates a conducive learning environment. Most especially, when I want learners to better understand concepts, I put myself at the centre of the teaching and learning process, and explain the knowledge to them for better understanding.

Respondent B:

I use the lecture demonstration method in teaching citizenship education because it gives me the opportunity to explain concepts accurately to learners and, especially, when introducing a new concept to them. Besides, some lessons require that I put myself at the center of the teaching and learning process to ensure that the learners better understand the concept.

In addition, 2 of the respondents agreed that they also make use of the lecture 
illustration method in presenting the concepts to the learners. To them, lecture illustration is highly appropriate because it enables them to explain the concepts on the charts easily. When using the chart to enhance learners' acquisition of knowledge, lecture illustration cannot be left out.

Respondent D:

Lecture illustration is very important as far as the teaching of citizenship education is concerned because it enhances the explanation of objects drawn on the charts. When planning my lesson, I make sure I include the illustration method because it facilitates the delivery of the contents. Some learners learn better when words are accompanied by pictures, or drawn objects they see. So, to make them to better understand the lesson, I present the notes by illustrating on the chart or board.

Respondent F:

I cannot teach without using the illustration method. This is because it enhances the delivery of lesson contents. Besides, learners pay more attention to the lesson if it is well explained by the teacher. Besides, using the map and pictures to present the content to the learners needs the assistance of an illustration method.

The findings show that 3 of the respondents make use of the discussion method in the teaching of citizenship, and affirm that it highly promotes learners' acquisition of knowledge.

Respondent:

I make use of the discussion method in all my lessons because I believe that citizenship education is a practical subject, and learners know much already as far as knowledge is concerned. So, using the discussion method makes the learners active participants in the teaching and learning process, and contributes enormously in the acquisition of knowledge. Using the discussion method, learners will have the free will to say whatever they think, thereby discovering their own learning.

Respondent D:

I use the discussion method in the teaching of citizenship education because it makes learners very active in the teaching and learning process. Discussion enables the learners to discover their knowledge themselves, thus making them responsible youths in the society. I believe every student knows something, and the best way to make them participate in the lesson is to throw concepts at them and allow them to ponder over and make contributions.

Respondent F:

I use discussion method because it makes the class lively, and students participate very well in the lesson. It also enables slow learners to learn from the 
fast ones. This helps to build their competencies, and makes them responsible individuals in their respective communities. The learners are coming from different environments and are familiar with the different issues that plague their respective communities. So the best way to get their contributions is to throw the concepts at them and allow them discuss in the class.

Respondents were asked why they don't make use of the other methods like Debate, Role Play, Questioning, and Exposition as proposed by the syllabus. Most of them complained about the time attributed to the subject, and the work load of their main subject area. To them, using Debate and Exposition is time consuming and stressful. They did not see the relevance of using other methods different from lecture demonstration, illustration and discussion.

Respondent C:

I don't make use of the other methods such as debate, exposition, and questioning because there is insufficient time for the subject, since I have just two periods in a week and a duration of $1 \mathrm{hr} 40$ mins. Debate takes a lot of time and energy so if I rely on it, I might end up not exhausting the syllabuses. Discussion and lecture demonstration to me are the best methods to use to present the lesson to the learners because it addresses all the worries they bring into the learning environment.

Respondent F:

Teaching using Debate and Exposition is time consuming. Besides, the period to cover the syllabus is too short given that I teach only twice a week. I am satisfied with the methods I use because my students always perform well after writing the test.

Respondent A:

I think the discussion method has some aspects of Debate, Role play and Exposition. So there's no need to keep on repeating the same methods when I do not even have the time. The discussion method has some aspect of debate in it because learners are given the opportunity to discuss among themselves and make contributions.

During observation, I realized that respondent $\mathrm{D}$ depended solely on the use of lecture method in the presentation of the lesson. From the beginning to the end, she used the lecture demonstration method. These methods were not really fit for the lesson because they did not give learners the opportunity to propose their own notion of the concepts. The lecture method was very successful in presenting the notes to the learners as the teacher used the textbook. But it made the class very passive as learners were only encouraged to take down notes and didn't contribute in the teaching and learning process. This made the objectives of the lesson not to be achieved.

During observation, respondent $\mathrm{D}$ made ample use of the illustration method. It was appropriate but it would have been better if this illustration method were 
followed with discussion. The teacher commanded the class, and this discouraged learners from making their contributions. They became very passive in the teaching and learning process since the teacher knew everything, and was just explaining and pouring out the notes. This method was not really suitable for the lesson.

During observation respondent A made use of the discussion method based on questions. The teaching method selected was highly suitable for the lesson because the learners participated very well thereby rendering the acquisition of knowledge simple. Through the use of the discussion method, learners were asked to list the different types of families they know and their components. They did this with ease, thereby attaining the objectives of the lesson. The class was so interesting that I acquired much from the learners' contributions.

The findings revealed that teachers depend on lecture demonstration, illustration, and discussion methods in the teaching of citizenship education. These methods are in compliance with those suggested or prescribed by the new syllabus in the teaching of citizenship education. But the teachers highly neglected the use of other methods prescribed by the syllabus, such as Role Play, Debate, Questioning, and Exposition which would have better facilitated the learners' acquisition of knowledge.

\section{Discussion}

The findings show that a majority of teachers do not have a copy of the new subject syllabus and rely on their old schemes to teach learners. This is very dangerous as the schemes do not reflect the changes that have been made in the new syllabus in relation to the teaching materials, contents, assessments and pedagogy. It is therefore, likely that these teachers' are using obsolete materials, contents, pedagogy and assessment strategies to teach and consequently, learners cannot develop the expected competences. It equally indicates an absence of pedagogic supervision which is assumed by the principal at the level of the school and the pedagogic inspectors at the divisional and regional levels in Cameroon education. These weaknesses in the syllabus implementation process indicate lack of motivation, commitment, and professionalism on the part of teachers of secondary schools which needs to be addressed if the goals of instruction are to be achieved at the end of secondary education.

At the level of the use of instructional materials in the teaching of citizenship education, the findings depicted that most teachers rely on the use of textbooks and a few complements this with the occasional use of charts in teaching the subject. Other teaching materials such as computers, monuments, resource persons, museums, television, and radio as prescribed by the syllabus are completely neglected by the teachers. The teachers argued that these materials are unavailable in schools, that the financial resources needed to purchase such materials and pay for the out of school visits are non-existent, and that the school environment-learning spaces-does not support the use of these materials. All 
these, naturally translated into poor quality teaching, make it very difficult for learners to acquire the knowledge, and develop the competences specified as learning outcomes of the subject syllabuses. The findings are in line with those of Felisa and Judith (1999) [22], who opined that in Latin America, most teachers rely on the use of textbooks as the major instructional material in the teaching of 2citizenship education. According to Felisa and Judith (1999) [22], the lack of the use of varied instructional materials, makes learners very passive.

In the same vein, Jesús (2002) [10], and Riley (1997) [23], argued that citizenship education instructors like those of other subjects face difficulties with the utilization of instructional materials resulting from insufficient knowledge about the availability of these materials, difficulty in selecting and using them appropriately, financial difficulties of teachers and institutions, and non-availability of electrical power supply, among others. Generally speaking, these materials may be available but to use them and sustain them to achieve desired academic goals and objectives, poses a very big problem, owing to the absence of in-service training (Jesús, 2002) [10].

With regard to teaching methods used in teaching citizenship education, the findings of this study showed that teachers depend largely on teacher-centred methods-lecture demonstration and lecture illustration-and discussion to a minimal extent, to the detriment of learner-centred methods which are the major teaching methods prescribed by the syllabus, and which are most suitable for enabling learners develop knowledge and competences. Observation of teaching and learning showed that teachers highly neglect the use of learner-centred methods prescribed by the syllabus, such as Role Play, Debate, Questioning, and Exposition. These better facilitate the learners' acquisition of knowledge because they methods elicit learners' active participation in the teaching and learning process (Keller, 2005) [14]. This contrasts with findings by Steven (2002) [24] whose study on the influence of teaching methods in the teaching of citizenship education in secondary schools in Virginia, United State of America, showed that teachers used the learner-centered teaching methods (discussion, exposition, group work, assignment) in the teaching of citizenship education.

The study contributes by indicating that the education stakeholders promoting the design and implementing of the new syllabus have not succeeded in diffusing it. Teachers have not been adequately trained in understanding and use of the new syllabus along with the new features. This is buttressed by teachers using different schemes of work-official and non-official-in teaching the subject. Teacher's lack of interest in aligning their teaching to the national goals of education, and the impunity teachers enjoy in using unauthorised schemes of work in teaching. It highlights the absence of motivation, teacher continuous training, and the respect of professional ethics in their practise.

\section{Conclusions}

Regarding the syllabus implementation process, most teachers do not have a 
copy of the subject syllabuses and are teaching using their own made syllabuses. This aggravates the situation, given that the new syllabus is the working document which provides the contents, and proposes teaching materials, methods, assessment strategies, and lesson format for the teaching of the subject.

At the implementation stage, the findings also revealed that teachers do not make use of the proposed instructional materials, such as computers, monuments, resource persons, field trips, museums which are supposed to engage students and enable them in the process to acquire the needed knowledge and develop in them the expected competences during the teaching and learning interaction. Observation carried out in classrooms, showed that some teachers do not even make use of instructional materials at all, and that the majority heavily relied on the use of textbooks in the teaching of citizenship education.

Teachers highly depend on the use of lecture method in presenting the content of citizenship education to the learners with little importance placed on discussion method and questioning while other learner-centred methods were completely ignored, despite the fact that citizenship education is a practical subject that requires active learner participation.

\section{Limitations}

The study was limited to an investigation of the influence of methods and materials, to the exclusion of assessments, content, and learning experiences on learners' acquisition of expressed outcomes in the subject syllabus. Teachers' readiness, perceptions, understanding and motivation to implement the new syllabus were not addressed. The study used a case study design, thereby focusing on a few schools and a few teachers, in a particular locality, and limits the findings from being generalizable. Administrative aspects of the teaching and learning process were equally not addressed.

\section{Recommendations for Policy}

The school administration should make sure that every citizenship education teacher possesses a copy of the new syllabus which prescribes the methods, materials and assessment strategies in the teaching of citizenship education. Copies of these syllabuses should also be placed in the school library to facilitate access for both teachers and students.

The relevant authorities or personnel should carry out sustained supervision of instruction of the subject to assist and guide teachers in learning to use the new teaching methods prescribed in the subject syllabus, as well as encourage peer observation and feedback in order to raise the quality of teaching.

There is the need for resource centers to be instituted in schools to serve as repositories of teaching resources that would be used to facilitate teaching and learning.

Demonstration lessons on citizenship education could, as well, be carried out by experts such as pedagogic inspectors, to enable the teachers acquaint them- 
selves with most appropriate methods of lesson presentation.

\section{Conflicts of Interest}

The authors declare no conflicts of interest regarding the publication of this paper.

\section{References}

[1] McLaughlin, T.H. (2003) Citizenship Education in England: The Crick Report and Beyond. Journal of Philosophy of Education, 34, 541-570. https://doi.org/10.1111/1467-9752.00194

[2] Darling-Hammond, L. (1998) Teachers and Teaching: Testing Policy Hypotheses from a National Commission Report. Educational Researcher, 27, 5-15. https://doi.org/10.3102/0013189X027001005

[3] Atabong (2013) Ordinary Level Citizenship for Cameroon Schools. Anucam Educational Books Plc., Limbe.

[4] Araya, K. (2007) Teaching Materials: A Critical Position about the Role They Play in the Language Classroom. Actualidades Investigativas en Educación, 7, No. 3.

[5] Johnson, S. (1998) Utilization and Benefits of Instructional Media in Teaching Social Studies Course. Malaysian Online Journal of Instruction Technology, 2, 1-4.

[6] Ogbondah, L. (2007) Provision and Utilization of Instructional Materials for Secondary Schools as Predictor of High Academic Standards. Nigerian Journal of Social Studies, 17, 131-143.

[7] Tambo, L. (2003) Principles and Methods of Teaching: Application in Cameroon Schools. University of Buea: ANUCAM Publisher, Limbe.

[8] Flaming and Mills, S. (2011) Communities of Practice and Politeness. https://www.researchgate.net/publication/284401389_Communities_of_Practice_an d_Politeness

[9] Russel, D. (1997) Perspectives on Alternative Assessment Reform. American Educational Research Journal, 39, 69-95. https://doi.org/10.3102/00028312039001069

[10] Rodriguez, J.R. (2002) Review and Analysis of Research and Initiatives on Curricular Materials. Honduras, Mexico.

[11] Loyens, S.M.M., Magda, J. and Rikers, R.M.J.P. (2002) Self-Directed Learning in Problem-Based Learning and its Relationships with Self-Regulated Learning. Educational Psychology Review, 20, 411-427.

[12] Bame. (2004) Teacher Professional Learning and Development: Best Evidence Synthesis Iteration. Ministry of Education, Willington, New Zealand.

[13] Dean, J. (1983) Organising Learning in Schools. British Journal of Education, 55, 127-128.

[14] Gagne, R.M., Wager, W.W., Golas, K.C., Keller, J.M. and Russell, J.D. (2005) Principles of Instructional Design. Performance Improvement, 44, 44-46. https://doi.org/10.1002/pfi.4140440211

[15] Constantino (1994) Effective Lesson Planning, Delivery Techniques and Classroom Management Suggestions.

https://www.kean.edu/ tpc/Classroom\%20Management/EFFECTIVE\%20LESSON \%20PLANNING\%20\&\%20Classroom\%20Mgmt.htm

[16] Cicek (2013) Teacher's Lesson Plan Based on 2013 Curriculum Used by English Teacher. 
[17] Richards, J.C. (1998) Beyond Training: Perspectives on Language Teacher Education. Cambridge University Press, Cambridge, p. 103. Revista Brasileira de Linguística Aplicada, 1, 217-219. https://doi.org/10.1590/S1984-63982001000100010

[18] Bloom, S. (1986) A Primer for Parents, Teachers and other Educators: All Our Children Learning. McGraw-Hill, New York.

[19] Keller, J.M. (1987) Development and Use of the ARCs Model of Instructional Design. Journal of Instructional Development, 10, Article No. 2. https://doi.org/10.1007/BF02905780

[20] Merriam, S. (1988) Case Study Research in Education: A Qualitative Approach. Jossey-Bass, San Francisco.

[21] Stake, R.E. (2006) Multiple Case Study Analysis. Guilford, New York, p. 82.

[22] Felisa and Judith (1999) The Emergence of New Citizenship: Looking into the Self and beyond the Nation. In: Steiner Khamsi, G., Torney-Purta, J. and Schwille, J., Eds., New Paradigms and Recurring Paradoxes in Education for Citizenship: An International Comparison, Elsevier Science, Amsterdam, 37-60.

[23] Riley-Doucet, C. and Wilson, S. (1997) A Three-Step Method of Self-Reflection Using Reflective Journal Writing. Journal of Advanced Nursing, 25, 964-968.

[24] Finkel, S.E. (2002) Civic Education and the Mobilization of Political Participation in Developing Democracies. Journal of Politics, 64, 994-1020.

https://onlinelibrary.wiley.com/doi/abs/10.1111/1468-2508.00160

https://doi.org/10.1111/1468-2508.00160 


\section{Appendix (Abstract and Keywords in French)}

L'impact des méthodes et du matériel didactique sur l'enseignement de l'éducation à la citoyenneté: Le cas des établissements scolaires de la municipalité de Buea

Résumé: La présente étude porte sur l'impact des méthodes et du matériel sur l'enseignement de l'Education à la citoyenneté dans les établissements secondaires de la Municipalité de Buea. Deux axes de recherche ont guidé cette étude: d'une part la corrélation entre les méthodes d'enseignement et l'enseignement de la Citoyenneté et d'autre part la corrélation entre l'utilisation du matériel didactique et 'enseignement de l'Education à la citoyenneté dans les établissements secondaires de la municipalité de Buea. L'étude adopte une approche qualitative, utilisant le modèle d'études de cas multiples pour mener l'enquête à l'aide d'un entretien et d'un calendrier d'observation. Elle implique 6 enseignants de l'Education à la citoyenneté de 3 établissement sélectionnés à savoir Summerset Bilingual High School Molyko, Government Bilingual Grammar School Molyko et Baptist High School Great Soppo. La procédure d'échantillonnage raisonné a été utilisée pour sélectionner les écoles et les enseignants participants à l'étude. Deux enseignants ont été interrogés, et un enseignant observé dans chaque établissement, pour savoir si les méthodes et le matériel utilisés correspondaient à ceux proposés par les programmes. Les données de l'entrevue et de l'observation ont été transcrites et codées par thème. Les résultats ont montré que les enseignants de l'Education à la citoyenneté utilisent principalement des méthodes d'enseignement centrées sur l'enseignant, contrairement aux méthodes centrées sur l'apprenant prescrites dans le programme. Les enseignants n'ont pas les programmes d'enseignement et ne comptent que sur les manuels pour leur enseignement de la matière.

Mots clés: méthodes d'enseignement, matériel pédagogique, l'influence, la citoyenneté, établissement secondaires, programme d'enseignement 